\title{
SISTEM PEMBINAAN DAN \\ PENGELOLAAN DANA PANTI ASUHAN ELISAMA
}

\author{
KADEK KRISNA ADITHA, KOMANG PUTRIYANI, NI KADEK RIA TRIANA, I \\ KADEK ANDA SUARBAWA, I KADEK ANDA SUARBAWA \\ Jurusan Akuntansi, Universitas Pendidikan Ganesha, Singaraja, Bali, Indonesia
}

\begin{abstract}
Abstrak
Penelitian ini bertujuan untuk mengetahui proses pelaksanaan pelayanan yang diperoleh anak asuh melalui pembinaan, bagaimana pola pembinaan yang diberikan, apa saja yang menjadi faktor-faktor pendukung dan penghambat pembinaan, dan apa saja dampak pelayanan yang diperoleh anak asuh melalui pembinaan. Hasil dari penelitian ini yaitu Pembinaan Pelayanan yang diperoleh anak asuh melalui pembinaan di Panti Asuhan Elisama bertujuan untuk memperbaiki diri anak asuh, menambah pengetahuan, menjadikan anak percaya diri dan tidak minder, dan mampu bersosialisasi sehingga kelak dapat menjadikan mereka menjadi sumber daya manusia yang berkualitas. Proses pembinaan di Panti Asuhan Panti Asuhan Elisama meliputi perencanaan, pelaksanaan pembinaan spiritual dan keterampilan serta evaluasi. Perencanaan meliputi rekrutmen anak asuh, menentukan jadwal, materi, metode dan media yang digunakan.
\end{abstract}

Kata kunci: Pembinaan, Pengelolaan, Dana

\begin{abstract}
This study aims to determine the process of implementing services obtained by foster children through coaching, how the pattern of guidance provided, what are the supporting factors and obstacles to coaching, and what are the effects of services obtained by foster children through coaching. The results of this research are Guidance Services obtained by foster children through coaching at Elisama Orphanage aims to improve foster children, increase knowledge, make children confident and not inferior, and able to socialize so that later they can make them into quality human resources. The coaching process at the Elisama Orphanage includes planning, implementing spiritual and skills training and evaluation. Planning includes the recruitment of foster children, determining the schedule, materials, methods and media used.
\end{abstract}

Keywords: Coaching, Management, Funds

\section{Pendahuluan}

Kemiskinan yang terjadi di Indonesia mengarah kepada kesulitan masyarakat dalam memenuhi kebutuhan primer dan kesulitan mereka dalam mendapatkan kehidupan yang layak. Kemiskinan yang terjadi di Indonesia tidak hanya memberikan dampak negatif pada orang dewasa saja, tetapi juga bagi anak-anak. Dampak yang terjadi pada anak baik sosial dan psikologinya menjadi terganggu. Hak mereka untuk memperoleh pendidikan dan masa kecil yang bahagia, berkualitas dan yang layak didapatkan oleh anak-anak telah hilang. Kemiskinan yang membelit keluarga mereka membuat peran mereka dalam keluarga pun bergeser, mereka juga ikut berperan dalam memenuhi nafkah keluarga. Fenomena anakanak yang bekerja di Indonesia juga berpengaruh pada jumlah anak-anak yang putus sekolah. Hal ini dikarenakan sebagian besar dari anak-anak yang bekerja tersebut terpaksa putus sekolah dengan berbagai alasan. Fakta tersebut sangat memprihatinkan, mengingat merekala penerus bangsa ini nantinya.

Anak merupakan karunia Tuhan yang harus dijaga, dididik, dirawat serta dipenuhi segala kebutuhan hidupnya. Sehingga kelangsungan hidup, perkembangan fisik dan mental serta perlindungan dari berbagai gangguan atau marabahaya yang dapat mengancam masa depan anak dapat tersedia. Anak merupakan aset terpenting dalam kemajuan dan 
pembangunan bangsa karena anak adalah generasi penerus perjuangan yang akan menghadapi tantangan masa depan. Untuk itu, pemenuhan kebutuhan anak harus terpenuhi baik kebutuhan jasmani maupun rohani. Seperti di jelaskan dalam Undang-Undang Perlingdungan Anak tentang Hak Dan Kewajiban Anak Pasal 8 yaitu setiap anak berhak memperoleh pelayanan kesehatan dan jaminan sosial sesuai dengan kebutuhan fisik, mental, spiritual, dan sosial. Masalah kemiskinan merupakan salah satu dari berbagai faktor pendorong anak tidak terpenuhi kebutuhan hidupnya Faktor-faktor lainnya seperti orang tua atau kedua orang tuanya sudah meninggal, rendahnya pengertian, ketidak mampuan dan kelalalaian orang tua terhadap pemenuhan hak-hak anak untuk tumbuh dan berkembang secara wajar yaitu terpenuhinya kebutuhan dasar dengan wajar baik rohani, jasmani maupun sosial, memperoleh pendidikan yang layak, dan memperoleh pelayanan kesehatan yang memadai membuat anak menjadi terlantar dan harus bisa hidup mandiri agar kebutuhannya dapat terpenuhi. Anak yang terlantar termasuk anak yang sudah tidak memiliki salah satu atau kedua orang tua merupakan anak yang memerlukan perhatian karena mereka perlu mendapatkan pemenuhan kebutuhan dasarnya, kasih sayang, bimbingan dan dididik agar mampu menjadi pribadi yang berdaya.

Salah satu cara yang dapat dilakukan oleh anak-anak yang telah kehilangan salah satu atau kedua orang tuanya adalah dimasukkan ke dalam suatu lembaga sosial yaitu panti asuhan agar mereka mendapat pembinaan selayaknya keluarga yang utuh. Anak-anak dengan masalah sosial tersebut perlu mendapat pembinaan atau pelayanan sosial dari lembaga sosial yang berfokus pada perlindungan anak seperti Panti Asuhan. Panti Asuhan merupakan salah satu lembaga non formal yang bergerak dalam pengasuhan anak dimana fungsi Panti Asuhan dalam pendidikan non formal adalah sebagai pelengkap dan penambah. Pelengkap maksudnya pendidikan nonformal dapat mengembangkan program-program yang menampilkan bahan ajar yang tidak dimuat dalam kurikulum pendidikan formal sedangkan penambah maksudnya pendidikan nonformal menyusun program yang dapat mewadahi atau dapat memberi kesempatan tambahan pengalaman belajar dari yang sudah didapat dalam program pendidikan forma. Bekal pendidikan diharapkan mampu mengubah kehidupan anak-anak agar hidup lebih layak karena anak telah dibekali ilmu dan keterampilan sehingga percaya diri dalam menghadapi kehidupan setelah anak tidak tinggal di Panti Asuhan. Makna pendidikan merupakan investasi setiap individu agar hidup dengan layak karena dengan bekal pendidikan setiap individu dapat mengembangkan segala potensi yang dimiliki. Di Indonesia penyelenggaraan pendidikan telah diatur dalam Undang-Undang RI No.20 Tahun 2003 tentang Sistem Pendidikan Nasional yang menyatakan bahwa "Pendidikan adalah usaha sadar dan terencana untuk mewujudkan suasana belajar dan proses pembelajaran agar peserta didik secara aktif mengembangkan potensi dirinya untuk memiliki kekuatan spiritual keagamaan, pengendalian diri, kepribadian, kecerdasan, akhlak mulia, serta keterampilan yang diperlukan dirinya, masyarakat, bangsa dan negara." Peranan pendidikan sangat penting dalam kehidupan dan kemajuan manusia karena pendidikan merupakan suatu kekuatan yang dinamis dalam kehidupan setiap individu yang dapat mempengaruhi perkembangan fisik, jiwa, sosial dan moralitasnya.

Secara esensial di dalam pendidikan terkandung pembinaan (pembinaan kepribadian), pengembangan (pengembangan kemampuan-kemampuan atau potensipotensi), peningkatan pengetahuan ( tidak tahu menjadi tahu). Dalam pendidikan terjalin hubungan dua pihak yang saling mempengaruhi yaitu terdapat transformasi pengetahuan, nilai-nilai dan keterampilan sehingga dapat mencapai tujuan yang di inginkan. Dalam Undang-undang RI No 20 Tahun 2003 Pasal 26 ayat 2 menyatakan yaitu "Pendidikan nonformal berfungsi mengembangkan potensi peserta didik dengan penekanan pada penguasaan pengetahuan dan keterampilan fungsional serta pengembangan sikap dan kepribadian profesional. Dengan pendidikan non formal, diharapkan setiap warga negara dapat memperluas wawasan pemikiran dan peningkatan kualitas pribadinya." Sebagai salah satu lembaga non formal yang bergerak pada pelayanan sosial anak, Panti Asuhan mempunyai peran untuk memberikan pelayanan bagi anak yang memiliki kesulitan dalam pemenuhan kebutuhan jasmani, rohani dan sosialnya. 
Seperti Panti Asuhan Elisama sebagai salah satu Panti Asuhan di Buleleng yang memberikan pelayanan kepada anak-anak yatim piatu dan anak-anak yang kurang mampu melalui pemenuhan kebutuhan fisik, psikis, dan sosial yang beralamat di Jl. Kresna, Kalibubuk, Buleleng, Bali. Panti Asuhan Elisama memberikan pelayanan yang diperoleh anak asuh meliputi pemenuhan pendidikan, pemenuhan pakaian dan makanan, pemenuhan kesehatan, serta pemenuhan rekreasi yang merupakan hak dari anak asuh dalam memenuhi kebutuhan jasmaninya. Pelayanan yang diberikan juga dalam bentuk kegiatan melalui pembinaan kepribadian dan kemandirian pada anak asuh yang mempunyai tujuan untuk menyeimbangkan potensi yang ada di dalam diri anak sehingga mampu menjadi pribadi yang berdaya, misalnya pembinaan aspek spiritual, pembinaan pengembangan potensi anak dan pembinaan aspek sosial. Agar tidak kehilangan seperti keluarga, panti asuhan berusaha memberikan pelayanan yang terbaik pada anak dan menjadikan anak- anak seperti keluarganya sendiri. Dalam proses penanaman jiwa kemandirian kepada anak asuh, pembinaan yang dilakukan memperhatikan aspek mental, spiritual, moral, intelektual, fisik dan psikisnya karena anak adalah sosok manusia yang masih memerlukan bantuan dan bimbingan dari orang yang lebih dewasa untuk mendidik, mengajar serta memberi perhatian.

Namun dalam pelaksanaannya pembinaan yang dilakukan yaitu pembinaan spiritual dan pengembangan potensi belum seimbang. Anak asuh yang menjadi binaan Elisama juga mendapat pelayanan melalui pembinaan keterampilan karena dengan bekal keterampilan yang di peroleh, anak asuh di harapkan dapat memanfaatkan bekal tersebut setelah mereka tidak tinggal di Panti Asuhan. Peran Panti Asuhan Elisama sebagai wadah dalam memberikan pelayanan terhadap anak asuh merupakan suatu bentuk realisasi kepedulian masyarakat terhadap anak-anak yatim dan anak yang kurang beruntung mendapat kasih sayang, perhatian serta pemenuhan terhadap kebutuhan hidupnya. Dijelaskan dalam Undang-undang Perlindungan Anak Bagian ke tiga tentang Kewajiban dan Tanggungjawab Masyarakat Pasal 25 berisi tentang kewajiban dan tanggung jawab masyarakat terhadap perlindungan anak dilaksanakan melalui kegiatan dan peran masyarakat dalam penyelenggaraan perlindungan anak. Di Panti Asuhan Elisama di lakukan kegiatan pembinaan terhadap anak asuh yang merupakan bentuk pelaksanaan pendidikan di dalam keluarga. Peranan orang tua di gantikan oleh pengasuh yang mempunyai tugas membina, mendidik dan mendampingi agar anak tetap merasakan kasih sayang dan mempunyai bekal untuk kehidupannya. Lingkungan sangat mempengaruhi perkembangan anak, karena anak mudah terpengaruh oleh lingkungan, jika lingkungan sekitar memiliki pengaruh buruk bagi anak maka anak akan berperilaku buruk juga tanpa adanya pendampingan yang baik dan pengawasan yang khusus, sedangkan jika lingkungan memiliki pengaruh baik maka anak akan berperilaku baik juga. Tetapi semua itu kembali pada pihak panti yang memberikan pelayanan dalam Panti Asuhan. Kurangnya pengawasan pengelola dan pengasuh yang jumlah SDM nya masih kurang akan membuat anak menjadi kurang perhatian sehingga minat anak asuh dalam mengikuti pembinaan masih rendah.

Dari jumlah pengasuh yang terbatas sehingga belum bisa memberikan perhatian yang lebih terhadap setiap anak asuh. Anak-anak asuh sangat membutuhkan perhatian dan kasih sayang dari pengasuh karena mereka menganggap bahwa orangtua pengganti adalah para pengasuh. Sering kali ada kecemburuan antara anak asuh karena dirinya merasa kurang diperhatikan. Pelayanan melalui pembinaan di Panti Asuhan merupakan pengembangan potensi anak, namun kondisi Panti Asuhan yang serba terbatas baik dari segi tempat, penyediaan fasilitas pendukung kemandirian anak dan pendanaan membuat program mengalami hambatan. Kegiatan pembinaan keterampilan yang berjalan namun tidak rutin yaitu membuat aneka handycraft dari barang bekas dan flanel, pembinaan memasak, pembinaan bakat anak.

Berdasarkan masalh diatas, maka rumusan masalah penelitian ini yaitu bagaimana proses pelaksanaan pelayanan yang diperoleh anak asuh melalui pembinaan, bagaimana pola pembinaan yang diberikan, apa saja yang menjadi faktor-faktor pendukung dan penghambat pembinaan, dan apa saja dampak pelayanan yang diperoleh anak asuh melalui pembinaan. 


\section{Hasil dan Pembahasan}

\subsection{Proses Pelaksanaan Pelayanan yang diperoleh Anak Asuh Melalui Pembinaan}

Dalam pelayanan yang diperoleh anak asuh diantaranya pemenuhan pendidikan, pemenuhan sandang, papan, serta pangan, pemenuhan kesehatan, dan pemenuhan rekreasi yang bertujuan untuk mendukung perkembangan potensi dan peningkatan tumbuh kembang anak sesuai yang diharapkan. Latar belakang anak asuh Rumah Yatim yang berasal dari keluarga ekonomi lemah, orang tua yang sudah meninggal, dan masalah sosial membuat mereka lebih baik mendapat binaan Panti Asuhan.

Dari hasil wawancara yang dilakukan dengan anak asuh Rumah Asuhan Elisama dapat disimpulkan bahwa mereka berasal dari keluarga yang berekonomi lemah dan orang tua yang sudah meninggal sehingga kurang mendapat perhatian baik kebutuhan jasmani dan rohani. Sesuai dengan misi dari Panti Asuhan yaitu memberikan pelayanan terbaik kepada anak-anak yatim piatu dan anak yang memiliki kekurangan ekonomi, maka Panti Asuhan menyediakan pelayanan program pembinaan kepribadian dan life skill supaya anak asuh dapat memperbaiki diri mereka, menambah pengetahuan, menjadi percaya diri dan tidak minder, dan mampu bersosialisasi di masyarakat ketika sudah keluar dari Panti Asuhan.

Pelayanan yang diperoleh anak asuh melalui pembinaan yang dilakukan di Panti Asuhan sangat berkontribusi terhadap perubahan diri anak asuh dan menambah pengetahuan. Anak asuh mempunyai persepsi bahwa pelayanan yang diperoleh memberikan banyak manfaat dan keterampilan kepada anak asuh dan hal ini dapat memotivasi anak asuh untuk percaya diri. Pelayanan yang diperoleh anak asuh melalui program pembinaan di Panti Asuhan Elisama bertujuan untuk menjadikan anak asuh sebagai orang yang professional dan memperbaiki taraf hidup masyarakat terutama kesejahteraan anak yang berkaitan dengan target atau sasaran Panti Asuhan Elisama.

Panti Asuhan Elisama mempunyai harapan kepada anak asuh untuk menjadi orang yang berguna baik dirinya maupun orang lain sehingga target atau sasaran dari Panti Asuhan dapat tercapai yang dilakukan melalui upaya pelayanan yang diberikan kepada anak asuh sehingga menjadikan dirinya termotivasi untuk memperbaiki diri. Peranan Panti Asuhan Elisama memberikan pelayanan pemeliharaan yaitu fasilitas pelayanan yang diperoleh anak asuh yang diberikan berupa pemenuhan kebutuhan sandang, pangan, kesehatan, pembinaan psikologi, pembinaan spritual dan bimbingan belajar, memberikan pelayanan kuratif dan rehabilitative berupa pembinaan kemandirian melalui pembinaan bakat, pembinaan keterampilan berupa keterampilan handycratf dan keterampilan memasak.

\subsection{Pola pembinaan yang diberikan}

Tahap Pelayanan yang Diperoleh Anak Asuh melalui Pembinaan Pelayanan yang diperoleh anak asuh melalui pembinaan di Panti Asuhan Elisama bertujuan untuk memperbaiki diri anak asuh, menambah pengetahuan, menjadikan anak percaya diri dan tidak minder, dan mampu bersosialisasi sehingga kelak dapat menjadikan mereka menjadi sumber daya manusia yang berkualitas. Pelayanan melalui pembinaan yang dilakukan di dalam Panti Asuhan Elisama dibagi menjadi ke dalam 3 Tahap, yaitu:

1. Tahap awal

Tahap dimana anak asuh Panti Asuhan masuk ke Panti Asuhan namun pembinaan yang dilakukan masih dalam tahap penyesuaian karena anak asuh masih homesick atau rindu keluarga sehingga masih diijinkan untuk pulang bertemu orang tuanya setiap dua minggu sekali. Pada tahap ini mereka mengalami masa-masa pengenalan yaitu:

a. Registrasi

Kegiatan ini mencatat informasi yang berhubungan dengan identitas diri, misalnya nama, alamat, agama, nama orang tua atau wali, alasan ingin menjadi anak Rumah Yati, dan sebagainya. Kegiatan ini penting dilakukan karena dengan registrasi ini data diri dari setiap anak asuh Panti Asuhan Elisama menjadi jelas sehingga apabila terjadi sesuatu terhadap anak asuh akan dapat diinformasikan kepada keluarganya. 
b. Orientasi

Kegiatan ini merupakan kegiatan dalam pengenalan Panti Asuhan Elisama, anak asuh dikenalkan dengan layanan pembinaan yang diperoleh anak asuh, peraturan serta hak dan kewajiban yang harus dipenuhi oleh anak asuh. Selain itu pada masa ini mereka diperkenalkan kepada Staf-staf pengelola panti tersebut.

c. Identifikasi Kebutuhan Anak Asuh

Kegiatan ini bertujuan untuk mencari informasi tentang potensi yang dimiliki oleh anak asuh dan kebutuhan apa yang diperlukan oleh anak dalam mendukung kegiatannya. Dalam akhir kegiatan ini akan mendapatkan gambaran potensi yang dimiliki oleh anak asuh. Mereka akan diberi kegiatan yang sama dalam program-program pembinaan yang merupakan pelayanan yang diperoleh anak asuh dan akan dievaluasi masing-masing anak asuh mana yang menonjol dan anak asuh yang masih membutuhkan adaanya layanan tambahan. Dari uraian di atas dapat disimpulkan bahwa mengidentifikasi bagi setiap anak asuh sangatlah penting dilakukan sehingga pelayanan yang dilakukan terarah dan hasil yang kemudian diinginkan akan lebih maksimal karena potensi yang ada dalam diri anak asuh Panti Asuhan Elisama diharapkan akan berkembang dan kelak akan menjadi SDM yang berkualitas. Kegiatan orientasi bagi anak asuh Panti Asuhan penting untuk dilakukan karena dengan kegiatan orientasi ini anak asuh akan lebih mengenal layanan pembinaan yang diperoleh anak asuh yang akan diberikan kepada mereka dan mereka juga mengetahui peraturan Panti Asuhan sehingga dapat menjadi pembiasaan bagi anak asuh serta mengetahui apa yang menjadi hak dan kewajiban mereka.

d. Identikasi Karakter Anak Asuh

Kegiatan ini dilakukan untuk mendapatkan informasi tentang latar belakang Anak Asuh Panti Asuhan Elisama dan merupakan kegiatan yang penting dilakukan untuk mengetahui karakter masing-masing anak asuh yang berbeda-beda sehingga dapat disesuaikan penanganannya.

2. Tahap Lanjutan

Pada tahap lanjutan ini anak asuh Panti asuhan Elisama meneruskan pelayanan pembinaan yang diberikan Panti Asuhan. Anak asuh sudah bisa menyesuaikan diri mereka dengan lingkungannya mulai dari melakukan rutinitas sehari-hari dan bersosialisasi dengan lingkungannya. Diharapkan dengan adanya rutinitas sehari dengan melibatkan lingkungan sosial disekitar Panti Asuhan dapat membuat anak asuh semakin percaya diri dan dapat menyesuaikan dengan kondisi sekitar, hal tersebut dilakukan untuk melatih kemandirian dan penyesuaian anak asuh jika kelak sudah kembali kekeluarganya.

3. Tahap akhir

Pada tahap ini anak asuh diberi pilihan untuk meneruskan keperguruan tinggi atau mengikuti kursus sesuai minatnya apabila telah menyelesaikan pendidikan formal sampai Sekolah Menengah Atas. Apabila anak asuh memilih untu melanjutkan keperguruan tinggi maka upaya yang dilakukan Panti Asuhan adalah memasukan anak pada lembaga bimbingan belajar yang telah berkompeten sedangkan anak asuh yang berminat untuk bekerja maka akan dimasukkan pada lembaga kursus sesuai dengan minatnya agar memiliki life skill yang dapat berguna untuk dirinya.

Pelaksanaan Pelayanan yang Diperoleh Anak Asuh Melalui Pembinaan Berikut ini adalah pelaksanaan pelayanan yang diperoleh anak asuh melalui pembinaan yang dilakukan di Panti Asuhan Elisama:

1) Perencanaan Kegiatan Pembinaan 
Perencanaan dalam melakukan pembinaan sangatlah penting untuk dilakukan agar dalam pelaksanaan pembinaan berjalan sesuai dengan tujuan. Perencanaan sebelum melakukan pembinaan dilakukan oleh pengasuh Panti Asuhan. Dalam perencanaan akan ditentukan jadwal, materi, metode, dan sarana dan prasarana yang dibutuhkan dalam pelaksanaan pembinaan nantinya. Pembinaan yang dilakukan disesuaikan dengan minat dan bakat yang diinginkan oleh anak asuh. Untuk mengetahui minat dan bakat dari anak asuh dilakukan pada tahap awal pembinaan yaitu mengidentifikasi kemudian akan disesuaikan dengan program pembinaan yang akan dilakukan.

2) Materi Pembinaan

Materi yang disampaiakan dalam pelaksanaan pembinaan disesuaikan dengan kompetensi masing-masing pengasuh dan pembimbing. Dalam penyampaian materi di setiap program pembinaan menggunakan bahasa yang sederhana dan terkadang menggunakan bahasa daerah sesuai dengan kemampuan berbahasa anak asuh serta terkadang diiringi cerita sehari-hari sehingga dapat membangun motivasi dan suasana kekeluargaan agar anak asuh semakin bersemangat untuk mengikuti pelayanan pembinaan dan membuat mereka lebih percaya diri.

3) Metode dan Media Pembelajaran Dalam Pembinaan

Metode pembelajaran yang dipakai pada saat pelaksanaan pembinaan sangat menunjang dalam penyerapan materi sehingga sangat bermanfaat untuk diaplikasikan dalam kehidupan anak asuh di Panti Asuhan Elisama.

4) Kegiatan Pelayanan yang Diperoleh Anak Asuh Melalui Pembinaan

Pembinaan yang dilakukan di Panti Asuhan Elisama dilaksanakan setiap hari Senin sampai Minggu. Kegiatan yang dilakukan berdasarkan jadwal kegiatan rutin yang telah ditentukan dan dilakukan di dalam Panti Asuhan Elisama. Berdasarkan pengamatan yang telah dilakukan menunjukan bahwa kegiatan pembinaan sudah terlaksana dengan baik karena sesuai dan terarah. Adapun jenis-jenis program pelayanan melalui pembinaan yang dilakukan di Panti Asuhan Elisama, yaitu:

a. Pembinaan Kepribadian

Pembinaan kepribadian yang dilakukan di Panti Asuhan Elisama bertujuan untuk membentuk anak asuh menjadi pribadi yang lebih baik dan menjadi anak yang berbakti kepada Tuhan, Orang Tua, Masyarakat dan Negara.

Adapun pembinaan tersebut meliputi:

1. Pembinaan Spiritual

Pembinaan spritual bertujuan untuk menjaga keseimbangan kehidupan didunia dan akhirat. Kebutuhan dunia dipenuhi melalui pelayanan yang diperoleh anak asuh seperti pelayanan pendidikan, sandang, papan, pangan, kesehatan dan rekreasi, sedangkan kebutuhan akhirat dipenuhi dengan memberikan bimbingan mental dan spiritual.

2. Pembinaan kesehatan

Pembinaan kesehatan merupakan pelayanan yang diperoleh anak asuh dari Panti Asuhan Elisama. Kegiatan yang dilakukan yaitu cek kesehatan anak asuh setiap enam bulan sekali. Kegiatannya tidak rutin setiap hari namun apabila ada anak asuh yang sakit langsung dibawa kedokter.

3. Pembinaan Psikologi

Pembinaan psikologi merupakan pembinaan yang berkaitan dengan kehidupan pribadi anak asuh. Pembinaan ini memberikan kebebasan anak asuh untuk berkonsultasi tentang masalah dan kehidupan seharihari mereka kepada pengasuh. Pembinaan ini diharapkan bertujuan untuk memberikan nasehat dan motivasi bagi anak asuh agar mereka mampu mengatasi kegelisahan dan masalah yang ada pada diri mereka. 
4. Pembinaan Kemandirian

Pembinaan kemandirian di Panti Asuhan Elisama diberikan dengan tujuan agar anak asuh dapat mengembangkan potensi dan bakat yang ada dalam diri anak asuh sehingga kelak akan berguna dan dapat diterapkan ketika sudah kembali kekeluarganya dan lingkungan masyarakat. Adapun pembinaan kemandirian yaitu:

(1) Pembinaan Bakat

(2) Pembinaan Bimbingan Belajar

(3) Pembinaan Memasak

5. Evaluasi Pembinaan

Setiap selesai kegiatan pembinaan yang dilakukan maka akan diadakan evaluasi pembinaan diakhir kegaiatan. Evaluasi yang dilakukan dapat melalui metode tanya jawab, pengamatan langsung dan raport untuk pembinaan tahsin serta hafan surat pendek. Untuk kegiatan yang bersifat praktek dapat digunakan metode pengamatan langsung dengan melihat hasil praktek anak asuh.

Pelayanan melalui pembinaan yang dilakukan di Panti Asuhan Elisama terhadap anak asuh sangat bermanfaat bagi perkembangan mental, fisik dan keterampilan mereka. Adapun manfaat pelayanan melalui pembinaan yang dilakukan di Panti Asuhan Elisama

terhadap anak asuh adalah sebagai berikut:

1) Pelayanan melalui Pendidikan Anak Asuh

Setiap anak asuh memiliki hak untuk memperoleh pelayanan pendidikan di Panti Asuhan Elisama. Panti Asuhan Elisama memfasilitasi anak asuh agar bisa mempuh pendidikan formal dengan menyediakan biaya pendidikan, alat tulis, buku pelajaran, seragam sekolah dan segala sesuatu yang dibutuhkan anak untuk mendukung pendidikannya. Dalam mendukung pendidikan anak asuh dalam hal akademik Panti Asuhan Elisama menyediakan fasilitas pelayanan bimbingan belajar yang pelaksanaannya disesuaikan dengan kebutuhan anak asuh.

2) Kondisi Psikologi Anak Asuh Panti Asuhan Elisama

Kualitas dari anak asuh akan tercapai apabila terpenuhinya kebutuhan jasmani dan rohani. Anak asuh akan merasa senang apabila mereka tetap mendapat perhatian baik di lingkungan Panti Asuhan Elisama maupun perhatian dari keluarganya. Panti Asuhan Elisama juga memberi keleluasaan keluarga dari anak asuh untuk melakukan kunjungan atau menjenguk anaknya yang menjadi anak asuh di Panti Asuhan Elisamaminimal tiga Bulan sekali.

3) Kondisi Sosial

Kehidupan anak asuh yang tinggal di Panti Asuhan Elisama tentunya sama ketika mereka tinggal bersama keluarganya namun yang membedakan jadwal kegiatan rutin yang mengatur membuat mereka terbatas kehidupan di luar Panti Asuhan Elisama sehingga hanya berkomunikasi dengan pengasuh serta pengelola Panti Asuhan Elisama dan anak asuh lainnya dengan baik. Komunikasi yang terjalin antara anak asuh dan pengasuh terjalin dengan baik.

4) Perubahan Sikap dan Perilaku Anak Asuh di Panti Asuhan Elisama Latar belakang anak asuh yang berasal dari kondisi keluarga tidak harmonis, keluarga ekonomi lemah, orang tua yang tidak lengkap membuat kepribadian mereka ada yang tidak percaya diri, tertekan, temperamental dan kurang sopan sehingga perlu adanya pembinaan. Dalam pembinaan perilaku seperti ini diharapkan dapat merubah pribadi merela lebih baik melalui berbagai bentuk pembinaan yang telah dilakukan di Panti Asuhan Elisama.

5) Pelayanan yang Diperoleh Anak Asuh melalui keterampilan 
Keterampilan perlu dimiliki oleh anak asuh Panti Asuhan Elisama karena dengan keterampilan yang ada dapat dijadikan sebagai modal mengembangkan potensi dan dapat dijadikan sebagai mata pencaharian. Pelayanan yang diperoleh anak asuh melalui keterampilan cukup memberikan manfaat bagi anak asuh.

\subsection{Faktor Pendukung dan Faktor Penghambat Pelayanan yang Diperoleh Anak Asuh Melalui Pembinaan di Panti Asuhan Elisama}

Dalam pelayanan yang diperoleh anak asuh melalui pembinaan di Panti Asuhan Elisama tentunya ada faktor pendukung dan penghambat serta dampak dalam penyelenggaraannya yang akan diuraikan sebagai berikut:

- Faktor Pendukung

Dalam pelayanan yang diperoleh anak asuh melalui pembinaan yang dilakukan di Panti Asuhan Elisama dalam pelaksanaannya terdapat faktor pendukungnya, yaitu:

$\checkmark$ Hubungan sosial pengasuh dan anak asuh

Dalam observasi yang dilakukan peneliti pada setiap proses pelayanan melalui pembinaan maupun kehidupan sehari-hari di Panti Asuhan Elisama hubungan antara anak asuh dengan pengasuh terlihat harmonis.

$\checkmark$ Potensi dan minat anak asuh

Pelayanan melalui pembinaan yang dilakukan berdasarkan minat dan potensi anak asuh sehingga akan memberikan motivasi dan tanggung jawab terhadap anak asuh dengan adanya pelayanan pembinaan yang dilaksanakan agar tujuannya dapat tercapai

$\checkmark$ Partisipasi anak asuh

Partisipasi anak asuh yang cukup tinggi dalam setiap pelayanan melalui pembinaan yang diberikan karena anak asuh merasa bahwa pembinaan yang diberikan akan bermanfaat untuk dirinya dan orang lain nantinya.

$\checkmark$ Hubungan kerjasama dengan pihak lain

Hubungan kerjasama antara Rumah Yatim dengan pihak lain seperti mahasiswa yang membantu pelaksanaan kegiatan pelayanan melalui pembinaan yaitu pembinaan psikologi, bimbingan belajar dan keterampilan.

- Faktor Penghambat

Dalam pelayanan yang diperoleh anak asuh melalui pembinaan yang dilakukan di Panti Asuhan Elisama dalam pelaksanaannya tentu ada faktor yang menghambat kegiatan pembinaan.

\subsection{Dampak Pelayanan yang Diperoleh Anak Asuh Melalui Pembinaan di Panti Asuhan Elisama}

Dalam pelayanan yang diperoleh anak asuh melalui pembinaan yang dilakukan di Panti Asuhan Elisama dalam pelaksanaannya tentu ada dampak terhadap anak asuh di Panti Asuhan Elisama. Berdasarkan pengamatan peneliti pembinaan yang dilakukan sudah cukup baik sehingga berdampak pada perubahan kondisi spiritual yang lebih baik dan taat dalam beribadah, akdemik yang baik, kondisi sosial yang baik dengan pengasuh dan pengelola maupun sesama anak asuh, bertambahnya ilmu dan keterampilan, dan perubahan sikap dan perilaku yang lebih baik.

\section{Simpulan dan Saran}

\subsection{Simpulan}

Berdasarkan uraian dari hasil penelitian dan pembahasan yang telah dilakukan, maka peneliti dapat menarik kesimpulan sebagai berikut:

- Proses pembinaan di Panti Asuhan Panti Asuhan Elisama meliputi perencanaan, pelaksanaan pembinaan spiritual dan keterampilan serta 
evaluasi. Perencanaan meliputi rekrutmen anak asuh, menentukan jadwal, materi, metode dan media yang digunakan.

- Pola pembinaan Di Panti Asuhan Elisama dilakukan secara rutin dan insidental dalam bentuk pembinaan kepribadian dan kemandirian. Pembinaan kepribadian meliputi pembinaan spiritual, kesehatan, dan bimbingan psikologi. Pembinaan kemandirian meliputi pembinaan bakat, bimbingan belajar, memasak dan keterampilan handycraft membuat aneka bros, gantungan kunci, tempat pensil, serta bunga plastic.

- Faktor pendukung pembinaan di Panti Asuhan Elisama adalah:

a. pengasuh dan pengelola Panti Asuhan Elisama yang ramah, perhatian terhadap anak asuh dan disiplin,

b. pelayanan melalui pembinaan yang dilakukan berdasarkan minat anak asuh sehingga akan memberikan motivasi dan tanggung jawab terhadap anak asuh dengan adanya pelayanan pembinaan yang dilaksanakan agar tujuannya dapat tercapai,

c. adanya bantuan pembinaan yang diberikan oleh mahasiswa yang bersedia ikut memberikan pembinaan terhadap anak asuh,

d. partisipasi anak asuh yang cukup tinggi dalam setiap pelayanan melalui pembinaan yang diberikan.

- Faktor Penghambat pelayanan melalui pembinaan di Panti Asuhan Elisama adalah:

a. minat atau antusias anak asuh mengikuti pelayanan melalui pembinaan masih kurang antusias,

b. masih kurangnya jumlah pengasuh atau SDM internal Rumah Yatim dalam memberikan pelayanan melalui pembinaan terhadap anak asuh,

c. masih kurangnya pendanaan untuk memenuhi fasilitas sehingga menjadi tertunda dalam pemenuhannya.

- Dampak pelayanan melalui pembinaan di Panti Asuhan Elisama adalah:

a. adanya kondisi spiritual untuk mendekatkan diri pada Tuhan yang lebih baik dan taat dalam beribadah,

b. meningkatan prestasi akademik di sekolah dengan mendapat rangking di sekolah,

c. untuk meningkatkan kondisi sosial yang baik anak asuh dengan pengasuh dan pengelola serta sesama anak asuh,

d. semakin bertambahnya ilmu pengetahuan dan keterampilan yang dimiliki anak asuh sebagai bekal kelak di masyarakat,

e. adanya perubahan sikap dan perilaku yang lebih baik dari anak asuh.

\subsection{Saran}

Berdasarkan kesimpulan dari hasil penelitian mengenai pola pembinaan di Panti Asuhan Elisama yang telah diuraiakan di atas, maka dapat diajukan beberapa saran yang berguna bagi Panti Asuhan Elisama, pengasuh dan anak asuh.

- Bagi Panti Asuhan Elisama

a. Hendaknya Panti Asuhan Rumah Yatim Arrahman meningkatkan kualitas pengasuh dengan mengadakan pelatihan bagaimana cara mendidik anak yang baik agar hasil pembinaan bisa maksimal.

b. Kurangnya SDM internal sehingga perlu ditingkatkan upaya pelatihan terhadap SDM internal dan kerjasama yang intensif dengan lembaga lain agar kekurangan SDM internal dapat diatasi.

c. Perlu ditingkatkan lagi upaya dalam memotivasi dan menyadarkan anak asuh dalam mengembangkan dirinya.

- Bagi Pengasuh

a. Dalam pelaksanaan pelayanan melalui pembinaan menggunakan metode penyampaian materi sudah cukup baik namun akan lebih baik apabila dalam beberapa penyampaian materi diselingi oleh permainan sehingga lebih menarik dan mudah diterima oleh anak asuh supaya 
tidak monoton. Selain itu media yang digunakan dalam penyampaian materi perlu ditingkatkan seperti penggunaan media pembelajaran elektronik yaitu LCD sehingga dapat menampilkan video dan gambar yang sesuai dengan materi sehingga dapat menarik perhatian anak asuh dan penyampaian materi lebih mudah.

b. Pada saat pelaksanaan pelayanan melalui pembinaan apabila ada anak asuh yang kurang memperhatikan sebaiknya ditegur secara langsung sehingga pembinaan yang dilakukan lebih efektif.

- Bagi anak asuh

a. Anak asuh secara aktif membantu dan memotivasi anak asuh lainnya untuk meningkatkan kesadaran pentingnya kegiatan pembinaan

b. Anak asuh hendaknya mengikuti kegiatan pembinaan dengan antusias dan kreatif.

\section{Daftar Pustaka}

Alex Sobur. (1986). Anak Masa Depan. Bandung: Penerbit Angkasa.

Andi Prastowo. (2011). Metode Penelitian Kualitatif Dalam Perspektif Rancangan Penelitian. Yogyakarta: AR-RUZZ Media.

Andini Sekar. (2010). Kaitan Kemiskinan dengan Meningkatnya Angka Pekerja Anak.Usia.Dini.Di.Indonesia..Diakses.dari.http://andinsekar.wordpress. com/2010/05/10/makalah-pengaruh-kemiskinan-terhadapperkembangananak/. pada tanggal 15 April 2014, Jam 17.00 WIB.

Sekretariat Menteri Muda Urusan Agama. (1978). Pola Dasar Pembinaan dan Pengembangan Generasi Muda. Jakarta: Departemen Pendidikan Dan Kebudayaaan.

Undang-Undang Republik Indonesia Nomor 23 Tahun 2002. Tentang Perlindungan Anak. Jakarta: BP Restindo Mediatama. 